\title{
Ortho-Stylistic Colorings of Technological Mediated Communication (TMC) Forms; With Reference to Instant Messaging
}

\author{
Hasan M. S. Jaashan ${ }^{1}$ \\ ${ }^{1}$ King Khalid University, Saudi Arabia \\ Correspondence: Hasan M. S. Jaashan, Associate Professor of Applied Linguistics, King Khalid University, \\ Saudi Arabia. E-mail: jssam2004@gmail.com
}

Received: January 23, 2014 Accepted: February 23, 2013 Online Published: March 30, 2014

doi:10.5539/ijel.v4n2p100 URL: http://dx.doi.org/10.5539/ijel.v4n2p100

\begin{abstract}
This time which is called the information time or the knowledge society, we daily encounter the invention of new types and styles of communications such as computers which become essentially present in our everyday life, and are now available at homes and in offices worldwide. Computer, with its two main shapes (desktops and laptops), has different types such as; PDAs, mobile phones, Blackberries, etc.; and different media like the internet, emails, chat, text messaging and others. We can expect that new ones will be invented. All these types and styles of communication gadgets lead to coining new terms and concepts that can potentially have different interpretations from context to context. These different types and styles of information and communication technologies impact the way people communicate and use language. They also have an impact on the way they read, write, and process information. This lead the Arab internet users like other people worldwide to use new/deviant orthographic forms of language for communication which become the bone of contention among Arab scholars.

This paper studies the orthographic and linguistic colorings of instant messages (IM) used by the Saudi and Qatari students. I intend to study this form/register of language linguistically to achieve the following goals;

1) What are the stylistic coloring and orthographic features of this new Arabic forms used in IM communication.

2) The possibilities of applying IM written form on other registers for communication.

3) The controversial views of the Arab scholars about the negative and positive impacts of using this form of a language on standard Arabic.
\end{abstract}

Keywords: ortho-stylistic coloring, planned deviation, wired countries

\section{Theoretical Study}

Bodomo (2010) poses two main questions regarding the twined relationship between language and technologies; the first is concerned with the causal relationship between new forms of language and new technologies and the second is twined with the internet and other information communication technological (ICT) tools and the way they change the forms and uses of language? He says that the idea of "change" as used involves both change in linguistic forms and change in use of language. The other concern is to look at change as modification of existing forms and uses and change as emergence of novel, original creations of language. For examples, change as modification involves abbreviations; such as writing the second person singular pronoun in English, You as $U$ and writing the verb See as $C$. The Change as creations involve the creation of unique forms or entirely new words that are directly linked with the information revolution, such as YouTube (noun), to (you tube) (verb) and a (you tuber) (noun), email (noun) to (e-mail) and e-mailer (noun). Another example from Arabic are; the word \{beiger بيجي (call) (noun) to beiger (to call) (verb)\}, the Urdu word \{( sidah=straight) is used in Arabic as سيده (noun) and (verb)\}. Change in the way in which we use language may involve the use of emoticons to express our feelings when we write. Emoticons are a salient feature of what has often been described in the literature as visual language (Horn, 1999).

The second idea is the relationship between language use and new invented technologies, is it casual or not? Some writers say there is no casual relationship between the emergence of new technology, in general, and the new ways in which language is used. Kress $(1998$, p. 53) is one of those who clarifies that “...when we look at 
the far-reaching and deep changes in forms of communication which characterize the present-email and its changing forms of language, for instance, it is tempting to attribute these changes to some technological innovation but erroneous to do so". Luke (2000, p. 83) also takes a similar position, believing that new forms of literacy practices do not simply emerge with technological change. Rather, "technologies always emerge as products of specific cultural practices, literate traditions, and the interests and desires of those groups who design and name them". Other writers like Adams (1990) and Baron (1984) stand on the opposite direction. They confirm that there is casual relationship between the inventions of new technologies and the new ways of language use. Adams (1996) says that "the new technologies are themselves dramatically changing the nature of the language we use". Baron (1984, p. 139) concludes that "[n]o one in the computer industry has any hidden agenda for using hardware or software development to alter human language. Yet technology can indeed drive linguistic and social change".

A more similar ideas is; what is the exact language we have to use on TMC? Obviously, English was the only language used, since the internet began in the USA. Another question is high-lightened why English, in particular Bodomo (2010) gives four main reasons for this. First, the internet began in the US; second, English is still regarded as an international language for global information exchange; third it has a fair amount of native speakers and many second language speakers worldwide, such that even native speakers of other languages still have the option to use English as well as their language on the internet. A fourth reason for the dominance of English on the internet is that there are quite substantial character inputting and encoding problems, which leads to difficulties in using other languages, especially those that do not have an alphabetical writing system such as Arabic.

Attempts have been made to solve the monolingual problem of the TMC and make it multilingual. The programmers try to develop codes compatible for most languages, known as the Unicode System. Second there are also some inputting systems in place for converting alphabetical writing into other orthographical systems such as Chinese and Japanese characters. A third way is to develop multilingual websites, situations in which the same information is written in several languages on the same website. A fourth way is to develop what is known as Real-time multilingual translators for on the spot translation of websites.

Crystal (2001), Danet and Herring (2007) clarify that World Wide Web (www) is a new communicative frontier, and despite the fact that English has traditionally dominated cyberspace as the language of Internet technology's inventors, the conquerors of web are increasingly the multilingual users in almost every country on earth who are benefiting from this new generation of participatory interfaces

Montgomery (2008) says that the mode of communication is a determining factor in the kind of language registers used, and the ambiguously informal atmosphere created by Internet communication lends itself to more personalized, stylized, fore-grounded and deviated language use, creativity, and vernacular language in order to indicate the identity. In the absence of other social cues, language users online demonstrate creativity and productivity in their utterances (Crystal, 2001), and these practices construct virtual identities based on highly language-dependent constructions of sameness and difference. This gives us conclusion that IM linguistic form is like other registers characterized by being a planned deviation and suitable for specific domain. (Chapman, 1987).

When investigating the many issues within multilingual internet communication, Arabic use online presents unique insights. Not only Arabic requires a non-Roman alphabet script and constitute a minority language online, but it also carries politically-charged associations with Islam, the geographic regions of the Middle East and North Africa, and the current international security hot topic and terrorism (Rasha, 2007). Thus, Arabic language use on the internet sheds light on innovative strategies for dealing with technological marginalization, the universality of certain cross-linguistic digital communication trends, the socio-political dimensions of online culture, and the interaction of authority, community, and identity.

The Arab bilingual are able to cope with technological tools by using English language. However, the majority of Arab net users know only Arabic. However, they use specific features and characteristics of Arabic linguistic forms parallel to other internet languages. For example; Most Arab students use a creative spelling system to circumvent the limitations of their Roman alphabetic phone keyboards. They use the same Roman alphabets for their counterpart in Arabic on one hand. On the other hand, the consonants which have no existence in Roman alphabet are replaced by numbers and symbols to correspond to the shape of the Arabic script letters (see Romanization). Diaglossic Arabic varieties (high and low varieties) have great presence in IM, and the study of TMC proves the presence of colloquial Arabic online: High Arabic is the language of print media, politics, and official business, while colloquial Arabic varieties exist in great numbers throughout the Arabic-speaking world 
and are used in everyday conversation and for personal or social purposes (Palfreyman \& Khalil, 2003). The preliminary evidence suggests that the internet provides a venue for two sociolinguistic occurrences, the translation of a spoken vernacular into writing and the mutual acceptability of colloquial usage online. In addition, code-switching between English and Arabic is common, demonstrating the ubiquity of technological education and software in English, as well as the local academic prestige associated with the English language. In the absence of a reality-based linguistic community, self-identity and group identity may be forged by the use of stylized orthography in combination with local vernaculars, and code-switching has long been considered an important feature of identity assertion. Descriptively, these Arabic language studies elucidate only a tiny sliver of the language's Internet usage. However, they are powerful in connection with other multilingual studies that show cross-linguistic trends in orthographic creativity, the prevalence of speech-like communication in the form of local vernaculars, and the challenges of establishing identity and community online. Crystal (1997) explains that the primary motivation behind using a slang unique to the internet is to ease communication and the slang on the Internet is often a way of indicating group membership. At the same time, IM is a unique new hybrid register, exhibiting a fusion of the full range of variants from the speech community-formal, informal, and highly vernacular.

\section{What is IM?}

The rate of Computer-mediated communication has developing rapidly since the launch the World Wide Web in 1990. And because of the mass popularization of the Internet, many forms of CMC in all languages became widely used. These different types of CMC can be differentiated on two parameters: the number of recipients of a message and (2) the synchronicity of the communicative event. Though it is possible to have multiple recipients in IM, it is primarily used for one-to-one dialogue. IM is also synchronous, since participants are "electronically present at the same time" (Paolillo, 1999, p. 2). Instant (or near-instant) reply is the norm, and spontaneous, real-time dialogue takes place. IM is unique in that it is the only one-to-one synchronous type of CMC. At the turn of the twenty-first century, a lot of teens all over the world had used an IM program (Randall, 2002, p. 21). The increasing of IMs' popularity among young people has raised concern from a variety of people, including parents, teachers, psychologists, and grammarians. This has opened a new and wide gate for the researchers to make numerous studies on the topic. IM allows the Internet users to communicate with friends, family members, and business colleagues in real time through personal texts. There are also a lot of emotion icons such as pictures, symbols, and cartoons available for the users used to express the feeling or emotion. Moreover, It seems that we gradually moved from a purely text-based CMC to include video-based CMC even though the text-based aspects are still prevalent. Nevertheless, IM is a largely text-based CMC. A registered user can choose to chat with certain partners by selecting the person whose status (e.g., online, offline, away) is shown in the contact list. The contact list is automatically opened as a pop-up window when the users log into the account, and then the dialogue box will be opened up for users to type and send the texts. IM users can open two or more dialogue boxes and communicate with more than one person simultaneously. They can also see whether one is in the process of typing within the communication situation. On the other hand, IM can also be seen as an asynchronous $\mathrm{CMC}$ as well because users may leave the messages to their conversation partners even though they may be offline and the messages will be sent to them once the targeted receivers log into their accounts.

\section{Methodology}

1) Data collected (sample of text-based IM)

2) Questionnaire ( given to university students)

\section{Practical Study}

Saudi Arabia and Qatar are ones of the most wired countries in the Arab world. There is thus the potential for a very active environment of TMC activities. According to a survey done, most of Saudi and Qatari students in secondary schools and universities use instant messaging (IM) to communicate with one another. They use a new and unique register of language suitable to their environment, and it is parallel to the conditions of technological tools that require a special linguistic forms. They invent and coin new words and new orthographic shapes which become common after sometimes of circulation. IM is used to chat freely with friends and this may help explain why language forms and uses of IM texts are always informal. It is because communications with friends are always conducted in a casual manner. In this study I tried to collect some coined written shapes used to write sentences and words in IM as much as I can. Then I tried to sort them out linguistically according to the features of TMC. I collected the data from students in Qatar university and King Khalid University. This case study will particularly look at the linguistic features produced by them in the course of the text-based computer-mediated 
communication practices. Some of the common orthographic features are as follows:

\subsection{Romanization}

Romanization is a system to represent the Arabic words or sentences with the Roman alphabets. Most of the IM users, who always use English keyboards, use Romanization in their communication because they say that they find this style is easier and faster in communication. It shows the high class prestige. Below are some of the examples I find in the data collected.

Table 1. Examples of romanization

\begin{tabular}{|c|c|c|c|}
\hline Romanization & $\begin{array}{l}\text { Original } \\
\text { words }\end{array}$ & Examples & English \\
\hline $3 l a$ & على & *3la el file* & On the file \\
\hline $6 l 3 t$ & 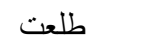 & *6l3t men el group* & I signed out from the group \\
\hline bl'3la6 & بالغلط & *Sawait lch delete bl'3la6.* & I deleted by mistakes \\
\hline 9ifini & ضيفيني & *9ifini Plz* & host me \\
\hline $5 l a 9 t$ & خلصت & *OK 5 la9 $9 t^{*}$ & Ok I finished \\
\hline 3adi & 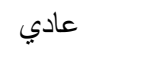 & *lesh 3adi 3ndch?* & Why is it normal for you? \\
\hline shukran & شكرا & *shukran ma89r6y* & Thanks, you did not fall short of. \\
\hline Mar7aba & 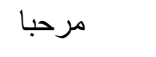 & ${ }^{*} H i, \operatorname{mar} 7 a b a^{*}$ & Hello, welcome \\
\hline ashofej & أشوفج & *wain ashofch.* & When can I see you? \\
\hline bukra & 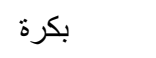 & *see u bukra*. & See you tomorrow \\
\hline wa 7 shtini & و وشتيني & *wa7shtini moot.* & I am dying to see you \\
\hline wayed & 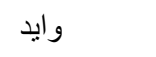 & *el class wayed 6weel.* & The class is very long \\
\hline 3afwan & 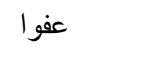 & *3afwan, what is time.* & Sorry, what is the time? \\
\hline la & ע & *la not yet.* & No, not yet \\
\hline$e e$ & 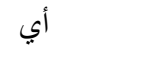 & ${ }^{*} E$ e finished el assignment. ${ }^{*}$ & Yes I finished the assignment \\
\hline Sh5barj & 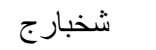 & ${ }^{*}$ she5barch today?* & How are you today? \\
\hline ro7ty & رحتي & *wain r7ty? * & Where did you go? \\
\hline$m a 3 r f$ & ماعرف & $* m a 3 r f$ arsem $*$ & I can't draw. \\
\hline $8 a 6 a r$ & قطر & $*$ fdait $8 a 6 a r^{*}$ & I redeem Qatar. \\
\hline
\end{tabular}

Stylistically, this new fore-grounded orthographic form (3la, 6l3t, bl'3la6, 9ifini, 5la9t, 3adi, shukran, Mar7aba, ashofej, bukra, wa7shtini, wayed, 3afwan, la, ee, Sh5barj, ro7ty, ma3rf,8a6ar) becomes common among IM users. It has no existence in the standard Arabic. It gathers number and letters to form words. The users intentionally deviate from the norms of standard and invent such funny forms for easy and economic communication.

\subsection{Arabization}

Arabization is the opposite of Romanization in which the English words and sentences are presented with Arabic alphabet. This kind of communication is used largely by those who find difficulties in using English keyboards or whose friend does not know English. In both Romanization and Arabization, the users mix between two languages. The other name of this is called code mixing. See the examples below: 
Table 2. Examples of Arabization

\begin{tabular}{|c|c|c|}
\hline Arabization & Original words & Examples \\
\hline \multirow[t]{3}{*}{ ل ماي } & Hi & هاي شخبارج \\
\hline & & *hi shekhparesh* \\
\hline & & Hi how are you? \\
\hline \multirow{3}{*}{ سي يو } & See you & أوكي سي يو ف الكلاس \\
\hline & & *Ok see you fi class* \\
\hline & & Ok see you in the class. \\
\hline \multirow{3}{*}{ كيوت } & Cute & شفتي اللي لابسته وايد كيوت \\
\hline & & *Shefty eli labistuh wide cute* \\
\hline & & You see what she is wearing. It is very cute. \\
\hline \multirow[t]{3}{*}{ سكارف } & Scarf & السكارف الاحمر احلى من الاخضر \\
\hline & & *Alskaref alahmer ahla men alakhdar* \\
\hline & & The red scarf is better than then the green one. \\
\hline \multirow[t]{3}{*}{ 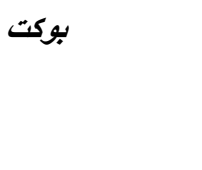 } & Pocket & حطي الورقه في البوكت عندج \\
\hline & & *Huty alwaraq fi al puket endidg* \\
\hline & & Put the paper in the pucket beside you \\
\hline \multirow[t]{3}{*}{ بزنس مان } & Businessman & 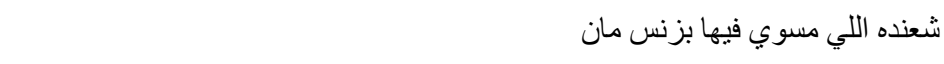 \\
\hline & & *shueduh alli musawi fiha businessman* \\
\hline & & What he has the one who makes himself businessman. \\
\hline \multirow[t]{3}{*}{ تلفقون } & Telephone & وين التلفون؟ \\
\hline & & *Ween altelefon* \\
\hline & & Where is my telephone? \\
\hline \multirow[t]{3}{*}{ الهووم وورك } & Home work & 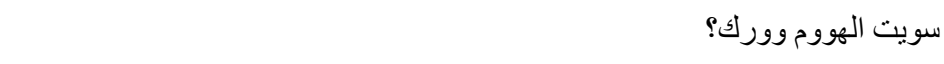 \\
\hline & & *Saweet al homwork* \\
\hline & & Have you done your homework? \\
\hline \multirow[t]{3}{*}{ البوكس } & Box & وين البوكس الأسود \\
\hline & & *Ween al box alaswed* \\
\hline & & Where is the black box? \\
\hline \multirow[t]{3}{*}{ بس } & Yes & يس أنا اهني \\
\hline & & *Yes ana hena* \\
\hline & & Yes I am here. \\
\hline \multirow[t]{3}{*}{ نو } & No & نو للحين ماخلصت الايسي \\
\hline & & *No lelheen ma khalest al ice* \\
\hline & & No. I haven't finished the ice yet. \\
\hline \multirow[t]{3}{*}{ كلاس +فنش } & Finish + class & اللحين انا فنشت الكلاس \\
\hline & & *Alheen ana finished al class* \\
\hline & & Just now I finished my class. \\
\hline \multirow[t]{3}{*}{ سيف } & Save & خلاص سيفها و ابعثها لي \\
\hline & & *Khalas saveha wa baath li* \\
\hline & & Ok, save and send me it. \\
\hline
\end{tabular}




\begin{tabular}{|c|c|c|c|}
\hline \multirow[t]{3}{*}{ 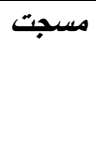 } & Send a message & & انا مسجت لله يجي الكلاس \\
\hline & & *Ana msggaed luh yegy al class* & \\
\hline & & Yes I messaged him to come to theclass. & \\
\hline \multirow[t]{3}{*}{ 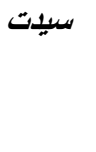 } & Indian word (go & & انا سيدت لما وصلت له \\
\hline & straight) & *ana saedt lama waselt luh* & \\
\hline & & I went straight till I found him. & \\
\hline
\end{tabular}

Arabization comes into existence because of the massive cultural constant contact between Gulf people and other nations; starting from the baby sitters at homes ending with professors in the universities at the academic level

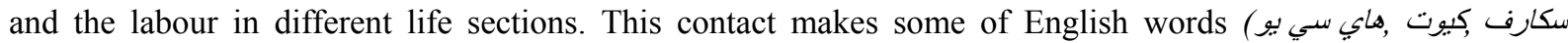
are part of daily communication in Saudia Arabia and Qatar. IM users, as well, are influenced by this trend and they use this form (Arabization) for communication.

\subsection{Abbreviated Words (Acronyms)}

Shortening is a common feature which can be found in the IM texts. English language has many examples in this concern. Some of the shortenings such as ASAP used in MSN texts can also be found before the use of MSN in various contexts like in letters and invitation cards. However, many of them are created and used pervasively only after the invention of the instant messaging; such as $\mathrm{U} / \mathrm{u}$ (you), tmr/tml (tomorrow), thx (thanks), 88 (Bye-bye), and bc/coz (because). Though shortenings are always done by acronyms, a word formation process, which forms words by combining the initial letters in a phrase or sentences, shortenings in IM are not limited to this formation method. As the popularity of IM is growing, language forms of IM texts are becoming richer through the development of new methods to form shortenings by numerous IM users. Among gulf students the Arabic abbreviated words of IM are found a lot at the level of words as well as at the level of sentences. See the examples;

Table 3. Examples of acronyms

\begin{tabular}{|c|c|c|}
\hline Abbreviated word & Target & Example \\
\hline \multirow[t]{3}{*}{ ف } & في in & قاعد ف السيارة. \\
\hline & & *Qaed $F$ alsayarh* \\
\hline & & You are sitting in the car. \\
\hline \multirow[t]{3}{*}{$\varepsilon$} & على on & المفتاح ع الطاولة. \\
\hline & & *Almuftah A attawelah* \\
\hline & & The key is on the table. \\
\hline \multirow[t]{3}{*}{ 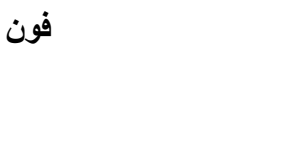 } & telephone تلفون & 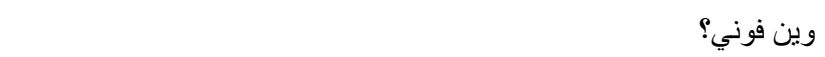 \\
\hline & & $*$ Wen phoni* \\
\hline & & Where is my telephone? \\
\hline \multirow[t]{3}{*}{ لاب } & laptop & اليوم بجيب لابي الجامعة. \\
\hline & & *alyoom bageeb labi aljameah* \\
\hline & & Today I will bring my lap to the university. \\
\hline \multirow[t]{3}{*}{ س1 - اس } & & السلام عليكم \\
\hline & & *assalam alikum* \\
\hline & & Peace be upon you. \\
\hline \multirow[t]{2}{*}{ 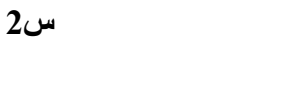 } & & و عليكم السلام \\
\hline & & *Waleekum alsalam* \\
\hline
\end{tabular}


Upon you be peace.

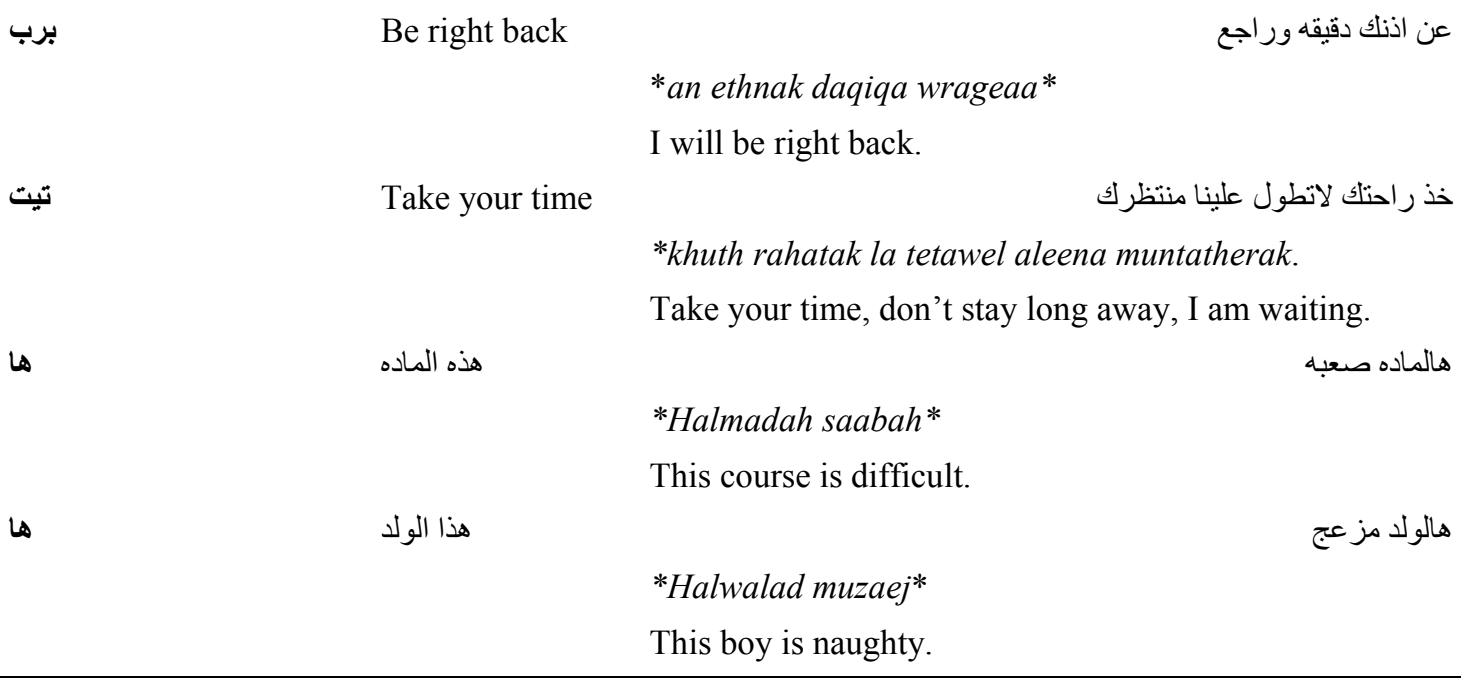

Gulf IM user like other people prefer economy in communication. They tend to have maximum results with minimum efforts. They use abbreviations in IM presupposing that the recipients understand them.

\subsection{Reduplication}

Reduplication involves copying the whole or the part of the words in IM. It is crucially used to express the emotional state of the mind or to draw the attention to it. The informants use this form widely as Arabization or Romanization. See below:

Table 3. Examples of reduplication

\begin{tabular}{|c|c|c|}
\hline Reduplication & English & Example \\
\hline \multirow[t]{3}{*}{ أي أي } & Yes yes & أي أي سمعت بهالسالفة \\
\hline & & *Ei ei sameat behaassalefa* \\
\hline & & Yes yes I heard this story. \\
\hline \multirow[t]{3}{*}{ وايد وايد } & Very very & وحشنتي قعدتكم و ايد و ايد \\
\hline & & *Wahshetny qaadetkum wide wide* \\
\hline & & I very very miss your staying. \\
\hline \multirow[t]{3}{*}{ 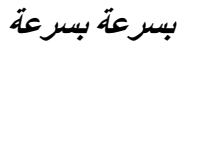 } & Quickly quickly & تعالي بسر عة بسر عة ننطر ج \\
\hline & & *Taali bisuraa bisuraa nentridg* \\
\hline & & Come quickly quickly we Are waiting for you. \\
\hline \multirow[t]{3}{*}{ ايوا ايوا } & Yes yes & ايوا ايوا هذا اللي اقصده \\
\hline & & *Yes yes hatha elli aqsuduh* \\
\hline & & Yes yes, this is what I mean? \\
\hline \multirow[t]{3}{*}{ 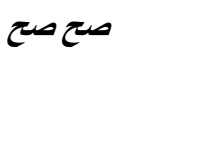 } & Right right & أي صح صح كلامج \\
\hline & & *Ei sah sah kalamej* \\
\hline & & Yes right right his speech. \\
\hline \multirow[t]{3}{*}{ هلا هلا } & Hello hello & هلا هلا و الله \\
\hline & & *Hala hala wallah* \\
\hline & & Hello hello, swear. \\
\hline 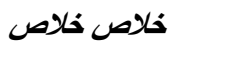 & Finish finish & خلاص خلاص فهت الموضوع \\
\hline
\end{tabular}


Finish finish I understood the case.

\begin{tabular}{|c|c|c|c|}
\hline \multirow[t]{3}{*}{ بياله بالله } & Ok ok & & يالله ياله خلج سريعة \\
\hline & & *Yallah yallah khaleej sareeah* & \\
\hline & & Ok ok be quick. & \\
\hline \multirow[t]{3}{*}{ 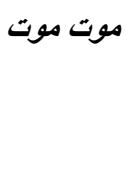 } & Very very & & اليوم حر موت موت \\
\hline & & *Alyoom har moot moot* & \\
\hline & & Today is very very hot & \\
\hline \multirow[t]{3}{*}{ ليش ليش } & Why why & & ل ليش ليش ماتبين اتجين؟ \\
\hline & & *Lysh lysh ma tbin atjeen* & \\
\hline & & Why why you do not want to come? & \\
\hline \multirow[t]{3}{*}{ تعب تعب } & Tiresome tiresome & & 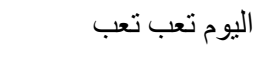 \\
\hline & & *alyoum ta'ab ta'ab* & \\
\hline & & Today is tiresome tiresome. & \\
\hline \multirow[t]{3}{*}{ حيل حيل ل } & Really really & & اليوم حيل حيل تعبت \\
\hline & & *alyoum heel heel ta'ebt* & \\
\hline & & Today really really I got tired & \\
\hline \multirow[t]{3}{*}{ 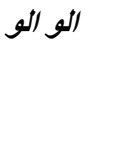 } & Hello hello & & الو الو معاك \\
\hline & & *allo allo ma'ak* & \\
\hline & & Hello hello I am with you. & \\
\hline \multirow[t]{3}{*}{$y$} & No no & & الا لا مو هالثكل قصدي \\
\hline & & *La la mo ha shakel qasdi* & \\
\hline & & No no I don't mean this shape. & \\
\hline
\end{tabular}

\subsection{Emoticonymy}

As people cannot always communicate face-to-face, no facial expressions and emotions can be seen. IM users then invent some ways to express their facial expressions through combinations of letters and strokes in the keyboard. Rather than a specific linguistic feature, emoticons are used worldwide and are developed into a quite standardized symbol system to express some common face expressions or emotions, for example, :) represents happy and :( represents unhappy. The examples below are samples of the emoticoymy commonly used by the informants. I think these shapes are common worldwide but they have regional meaning and applicable to be used and understood the way the communicators need. Some common forms are:

Table 4. Examples of emoticonymy

\begin{tabular}{ll}
\hline Emoticons & Target expression \\
\hline$\left.::^{\wedge}\right)^{\wedge}$ & Smiling happy \\
$:($ & Sad \\
$;)$ & Winking \\
$: P$ & Smile with tongue out \\
$: D$ & Big smile \\
$: \$$ & Shy \\
a@ & Watching \\
$*_{-} *$ & Surprised \\
\hline
\end{tabular}




\subsection{Creating New Randomly Words}

The informants sometimes use words that are created randomly or it would paste upon other languages as daily use for IM. This creation damage Arabic language, as some Arab scholars said, because this form is totally deviant from the standard grammar and structures. For example, some users apply the English structure in the Arabic words. They also create new words by mixing English words with Arabic morphology and vice versa. This may make the reader cannot understand the word because he/she do not know it before but after sometimes of circulation, this form becomes part of IM use. See the examples below:

Table 5. Examples of creating new randomly words

\begin{tabular}{|c|c|c|}
\hline Arabic word & English word & New form \\
\hline خربطاشن/خربطه & Rubbish & 5rbitation \\
\hline يمقن/يمكن & May be & Yumqen \\
\hline خلصت/فنشت & I finished & Ana fannashtuh \\
\hline حفظت/سيفته & I saved it & Ana saiftuh \\
\hline
\end{tabular}

\subsection{Arabic Letters Turn into Symbols, Numbers and Latin Letters}

This is called mode mixing or combination of letters and numbers. The informants use Latin letters/symbols/numbers instead of the Arabic letters which have no parallel existence in keyboard. For example, they will use 2 as \&, 3 as $\varepsilon$ and " 3 as $\dot{\varepsilon}$. So the worite as "mar7aba". These transformations which happen to Arabic language upon TMC users makes the users start to forget the correct spelling of Arabic letters. In addition, these forms of writing are hard to understand for some people because they must have the knowledge symbols, numbers and Latin letters corresponding to each Arabic letter. The data collected shows the equivalent number for the Arabic alphabetic letters which have symbols in the keyboard. See the examples below;

$$
3=\varepsilon \quad 6=b \quad 3=\dot{\varepsilon} \quad 9=\omega \quad 5=\dot{\tau} \quad 7=\tau
$$

Table 6. Arabic letters turn into symbols, numbers and Latin letters

\begin{tabular}{|c|c|c|}
\hline IM form & English & Arabic word \\
\hline $3 l a$ & on & على \\
\hline $6 l 3 t$ & sign out & طلعت \\
\hline bl'3la6 & by mistake & بالغلط \\
\hline 9eifini & host me & ضيفيني \\
\hline $5 \operatorname{la} 9$ & finish & خلاص \\
\hline 3adi & normal & عادي \\
\hline shukran & thanks & شكرا \\
\hline Mar7aba & welcome & مرحبا \\
\hline ashofech & see you & أشوفج \\
\hline bkra & tomorrow & بكرة \\
\hline wa 7 shtini & I miss you & وحشتيني \\
\hline wayed & very & و و ايد \\
\hline 3afwan & sorry & عفو \\
\hline$L a$ & no & $\gamma$ \\
\hline$E e$ & yes yes & أي \\
\hline Sh5barech & how are you & شخبارج \\
\hline ru7ty & you went & رحتي \\
\hline$m a 3 r f$ & I don't know & ماعرف \\
\hline 8e6er & Qatar & قطر \\
\hline
\end{tabular}


The data collected is sample of the registered form used for communication in Saud Arabi and Qatar. This style of language is commonly and widely used among youth not only in the mentioned countries but all over the Arabic speaking countries. The common point in Arabic TMC is the prevalence use of low variety of Arabic with its different regional dialects.

\section{Questionnaire Analysis}

The purpose of the questionnaire is to demonstrate the general trend of using instant messaging among the Saudi and Qatari students. It aims to know the orthographic linguistic features of the instant messages used by them. It is consisted of 5 qualitative questions and three quantitative ones. It is distributed to the informants through emails and hand to hand. The number of informants is 25 university students from Qatar university and King Khalid university in Saudi Arabia.

The first question asks the informants to clarify whether this orthographic form of a language is an alternative form of daily life or standard Arabic. 21 students are with the idea of using it as an alternative form of daily life communication and 4 informants are with the second option which is an alternative of standard Arabic. They say that they sometimes use this form in writing formal asynchronic letters. They added that they use this register in only $\mathrm{CMC}$ and no way to have it in other registers.

In the second questions, 18 students say that they use English numbers and letters instead of Arabic letters because the keyboard has not all Arabic letters. 5 students say using English letters is easier for them than Arabic. 2 students say they use it to save time.

15 informants in the third question prefer using code mixing. However, 5 informants use Romanization, 3 informants use Arabization and 2 use English. They assured that the recipient is the one who makes them select the forms.

In the $4^{\text {th }}$ question, 14 informants prefer this form of a language because it does not consider the grammatical rules of Arabic. 9 informants say they use it because it makes some messages private and can be deciphered only by those who know the code. 2 informants say they use emoticons to express the feeling instead of long sentences.

Most of the informants (18) in the $5^{\text {th }}$ question say they use this form of language every day. 5 informants use it once a week whenever necessary and 2 use it once a month and they always use standard forms in IM.

The sixth question clarifies that 16 informants use instant messages for chatting and 9 of them use it for homework because they find it interesting and convey ideas quickly.

The second part of the questionnaire which is qualitative has three sections; the first one asks the informants about the extent they consider the spelling and grammar of Arabic while communicating through CMC tools. The majority of the informants say that they do not pay attention to the correct spelling and grammar because in TMC tools the intelligibility has the priority over spelling and grammar. Moreover, considering spelling and grammar in TMC tools wastes time and increases the number of characters which are unnecessary.

The second and the third sections ask the informants whether this register has negative or positive impact on standard Arabic. Most of them say it has negative impact and it seriously affects standard Arabic. They add that the current generation is already weak in using standard Arabic, so such informal register will add insult to injury in deteriorating formal Arabic and melt them into western culture, but they added that the technology forces them to use this form.

10 of the informants are with the trend that this kind of language has positive impact on Arabic Language. It shows the flexibility of Arabic to be updated technologically like other world languages. They add that such general trend to use this register pressurizes the Arabic linguists and technology programmers to think over on how to make Arabic language included in TCM. They added that there are some Arab linguists who are with using this form of language to cope with technology and to maintain Arabic as well.

\section{Conclusion}

This planned deviant register of language has been the bone of contention among the Arab scholars. Some of the informants under study regard it as a healthy phenomenon that gives dynamicity to the language and opens a new gate for it to cope with the massive technology of communication. They justify their trend by saying that if we do not accept and modify this register as part of our language, then we will find our language in a corner and aloof from the world and out of technology. This view is supported by Some Arab linguists who consider Arabic as other languages should be open for all registers. I support this point because, stylistically, this form of language communication comes under the term (planned deviation) and David Crystal describes these language 
changes, both in form and use, as leading to a new form/register of language which he refers to as "Netspeak". The users of it deliberately deviate from the Arabic language norms. Since the Arabic language accept the register/forms of literature, advertisement, election, preaching..., etc., with their being deviant or fore-grounded as different registers of Arabic language, we should receive the linguistic form of TMC as a new and welcome register of Arabic language as well. If we criticize it as something bad, then we will find the next generations are rebellious against Arabic language and regard it as primitive and out of technology. But I am with the view of regarding TMC register as part and parcel of Arabic linguistics. And the Arab linguists should try their best to modify and study it linguistically and put some linguistic rules for using it (AlZaghol, 2008). Interestingly, this register has the limit of using in technological tools for personal communication only; it cannot be used as written form in press, or documents..., etc.

On the other hand, those who are against this idea confirm the risk the language faces because of this new kind of communication. Innumerable articles in the popular press suggest that the increasing use of IM by teens is leading to a breakdown in the Arabic language. They clarify that this register is the bastard of language and it breaks the spelling, morphological and syntactic form of it. Consequently, within span of time the language will be alien to generation. Moreover, the constant use of this register among young generation let them think that this form of a language is an original form of Arabic. This will support the orientalists' idea of writing in dialects instead of standard Arabic. They add that the massive use of this form will delete 8 letters of Arabic because they have no equivalence in Latin which is the keyboard alphabets. These letters are $\tau, \boldsymbol{\nu}, \boldsymbol{\nu}, \boldsymbol{b}, \dot{b}, \mathcal{\varepsilon}, \dot{\tau}, \dot{\varepsilon}$.

They strongly recommend stopping use this form among youth by conducting programs in schools, universities, explaining the risk of using this form of language on standard Arabic and encourage them to use Arabic instead.

Most of the invented orthographic forms carry one to one correspondence between the written form invented and sound, i.e., no double letter for one sound and no double sounds for one letter and this maintains Arabic rule.

\section{References}

Adam, A. (1996). Language awareness and information. Curriculum and Teaching, 11(2), 69-76. http://dx.doi.org/10.7459/ct/11.2.09

Baron, N. S. (1984). Computer mediated communication as a force in language change. Visible language, 18(2), 118-141.

Bodomo, A. B. (2010). Computer mediated communication for linguistics and literacy. U.S.A.: Information science references.

Brenda, D., \& Susan, C. H. (Eds.). (2007). E Multilingual Internet: Language, Culture, and Communication Online. New York, NY: Oxford University Press.

Chapman, R. (1987). Linguistics and literature: An introduction to literary stylistics. Totowa, N.J.: Littlefield, Adams.

Crystal, D. (2001). Language and the Internet. Cambridge: Cambridge University Press. http://dx.doi.org/10.1017/CBO9781139164771

David, P., \& Muhamed, A. (2009). "A Funky Language for Teenzz to Use”: Representing gulf Arabic in Instant Messaging. Journal of Computer-Mediated Communication, 9(1). Retrieved from http://jcmc.indiana.edu/vol9/issue1/

Horn, R. (1999). Visual language: Global communication in the 21th century. Macrovu Inc.

Kress, G. (1998). Visual and verbal mode of representation in electronically mediated communication: The potential of new forms of text. In I. Synder (Ed.), Page to screen: Taking literacy into the Electronic Era (pp. 53-79). London and New York: Routledge. http://dx.doi.org/10.4324/9780203201220_chapter_3

Luke, C. (2000). Cyper-schooling and technological change: Multi literacies for new times. In B. Cope, \& M. Kalantzis (Eds.), Multiliteracies: Literacy Learning and the Design of Social Future (pp. 69-91). Australia: Macmillan.

Paolillo, J. (1999). The Virtual Speech Community: Social Networks and Language Variation on IRC. Journal of $\begin{array}{llll}\text { Computer-Mediated } & \text { Communication, } & \text { 4(4). } & \text { Retrieved }\end{array}$ $\mathrm{http}: / / \mathrm{jcmc}$.indiana.edu/vol4/issue4/paolillo.html

Rasha, A. A. (2007). Islam, Jihad, and Terrorism in Post-9/11 Arabic Discussion Boards. Journal of Computer-Mediated Communication, 12, 1063-1081. http://dx.doi.org/10.1111/j.1083-6101.2007.00363.x

Wright, S. (2006). Language and the Internet. Sociolinguistica, 20, 166-182. 


\section{Copyrights}

Copyright for this article is retained by the author(s), with first publication rights granted to the journal.

This is an open-access article distributed under the terms and conditions of the Creative Commons Attribution license (http://creativecommons.org/licenses/by/3.0/). 